The Revival of British Liberalism 
This page intentionally left blank 


\title{
The Revival of British Liberalism
}

From Grimond to Clegg

\author{
Tudor Jones
}




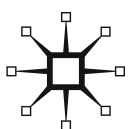

(C) Tudor Jones 2011

Softcover reprint of the hardcover 1st edition 2015 978-1-4039-4428-3

All rights reserved. No reproduction, copy or transmission of this publication may be made without written permission.

No portion of this publication may be reproduced, copied or transmitted save with written permission or in accordance with the provisions of the Copyright, Designs and Patents Act 1988, or under the terms of any licence permitting limited copying issued by the Copyright Licensing Agency, Saffron House, 6-10 Kirby Street, London EC1N 8TS.

Any person who does any unauthorized act in relation to this publication may be liable to criminal prosecution and civil claims for damages.

The author has asserted his right to be identified as the author of this work in accordance with the Copyright, Designs and Patents Act 1988.

First published 2011 by

PALGRAVE MACMILLAN

Palgrave Macmillan in the UK is an imprint of Macmillan Publishers Limited, registered in England, company number 785998, of Houndmills, Basingstoke, Hampshire RG21 6XS.

Palgrave Macmillan in the US is a division of St Martin's Press LLC, 175 Fifth Avenue, New York, NY 10010.

Palgrave Macmillan is the global academic imprint of the above companies and has companies and representatives throughout the world.

Palgrave ${ }^{\circledR}$ and Macmillan ${ }^{\circledR}$ are registered trademarks in the United States, the United Kingdom, Europe and other countries.

\section{ISBN 978-1-349-52244-6 ISBN 978-0-230-29492-9 (eBook)}

DOI $10.1057 / 9780230294929$

This book is printed on paper suitable for recycling and made from fully managed and sustained forest sources. Logging, pulping and manufacturing processes are expected to conform to the environmental regulations of the country of origin.

A catalogue record for this book is available from the British Library.

A catalog record for this book is available from the Library of Congress.

$\begin{array}{llllllllll}10 & 9 & 8 & 7 & 6 & 5 & 4 & 3 & 2 & 1\end{array}$

$\begin{array}{llllllllll}19 & 20 & 18 & 17 & 16 & 15 & 14 & 13 & 12 & 11\end{array}$ 
To the memory of my parents, Brynmor and Eilonwy 
This page intentionally left blank 


\section{Contents}

Preface viii

Acknowledgements $\quad$ x

Chapter 1 Survival of a Creed: 1945-1956 1

Chapter 2 The Advent of Grimond: the Creed Revived: 1956-1959 7

Chapter 3 Of Progress, Realignment and Disappointed Hopes: 1959-1967 28

Chapter 4 The Rise of Community Politics in Uncertain Times: 1967-1976 52

Chapter 5 Liberalism in a Cul de Sac: 1976-1979 76

Chapter 6 Liberalism within the Alliance: Denting the Mould: 1979-1983

Chapter 7 Liberals, Owen and the Social Market Economy: 1983-1988 118

Chapter 8 Recovery after a Painful Infancy: 1988-1997 143

Chapter 9 Ashdown's Unfinished Project: 1997-1999 166

Chapter 10 Advance and Debate: 1999-2005 178

Chapter 11 Crisis, Consolidation and Reaffirmation: 2005-2007 202

$\begin{array}{ll}\text { Conclusion } & 217\end{array}$

$\begin{array}{ll}\text { Chronology } & 224\end{array}$

Notes $\quad 232$

$\begin{array}{lr}\text { Select Bibliography } & 268\end{array}$

$\begin{array}{ll}\text { Index } & 274\end{array}$ 


\section{Preface}

This book provides an historical study of British Liberalism spanning the period from Jo Grimond's accession to the leadership of the Liberal Party in November 1956 to Nick Clegg's election as Leader of the Liberal Democrats just over 51 years later in December 2007. The book is therefore a history of Liberal ideas, as they were developed within the British Liberal Party and, later, the Liberal Democrats during that period. As such, it is concerned with organised, party Liberalism, not with philosophical liberalism or with liberal ideology conceived more broadly in cross-party terms. More precisely, perhaps, it could be said that this book is an ideological history of the Liberal Party and the Liberal Democrats since 1956. For its focus is on political ideas not only as they have been propounded in the writings and speeches of Liberal and Liberal Democrat politicians, thinkers and activists, but also as they have been embodied in the policies, programmes and strategies of their parties.

The text of this book was completed before the British General Election of 2010, and the subsequent formation of the Coalition Government, and with it the first direct Liberal participation in government since Churchill's wartime Coalition. That development in itself adds, I believe, increased relevance to the title of this book. It will be left to subsequent studies to assess the record of the Coalition and of Liberal Democrat ministers within it.

To a large extent the methods of the historian of political thought have been employed throughout this study - including detailed attention to such published sources as the books, pamphlets and periodicals which form, together with party policy documents and election manifestos, the main receptacles of British Liberal thought during the period under scrutiny. I have also drawn throughout upon material contained in two of the principal histories of the Liberal Party, parts of which cover the post-1945 period. These are: David Dutton, A History of the Liberal Party in the Twentieth Century, and Chris Cook, A Short History of the Liberal Party. In addition, this study draws upon unpublished Liberal Party papers and upon my own interviews and conversations with some of the leading Liberal and Liberal Democrat protagonists in the ideological and policy debates of those years.

In researching and writing this book, I have examined, and in some cases uncovered, what I believe to be a rich and varied seam of Liberal writing since the 1950s, one, too, that in some respects has been neglected or undervalued. In quoting widely, and at times extensively, from such material I have tried to let those literary expressions of Liberal thought speak for themselves down the years. I have, however, inserted my own interweaving commentary and in places, of course, my own interpretation and analysis. 
I have also quoted at length from Liberal, SDP/Liberal Alliance and Liberal Democrat statements of principles and general election manifestos in the post-1945 period. In the case of the latter, my justification for doing so is that, as Duncan Brack has pointed out, manifestos have held a particular significance for members of the Liberal Party and the Liberal Democrats. The reasons for this are really twofold. First, apart from their main function of conveying their parties' principles and policies to the electorate, election manifestos have also been important tools of communication within the Liberal Party and the Liberal Democrats. ${ }^{1}$ For as the most public expressions of the parties' political philosophy, namely, Liberalism, with its set of core values and beliefs, manifestos have thus helped to unify those parties, imbuing them with a sense of identity, purpose and direction. This has been particularly important, too, in view of the fact that, unlike their major rivals, the Liberal Party and its successor have lacked a firm base in class or sectional interests. Second, because British Liberals had been out of office since the time of Churchill's wartime coalition, they could not rely on their own governmental record as a source of motivation and party unity. Policy development and debate have therefore 'offered an alternative driving force', which has consequently shaped the organisational structures of both the Liberal Party and the Liberal Democrats. ${ }^{2}$ Election manifestos have, again, been the clearest expressions of that process. All of the above comments apply, too, of course, to the parties' periodic statements of principles, which, in the case of the Liberal Democrats, have been referred to as 'themes and values' documents.

Essentially, however, this book remains a history of Liberal ideas since the 1950s, viewed within the context of the major events and developments affecting the Liberal Party and its successor. (These are summarised in the Chronology at the end of the book.) It seeks to demonstrate a clear pattern of continuity of Liberal values, principles and themes, and also, to a large extent, of policy. It describes, too, the manner in which new and often creative ideas and policy thinking emerged during the main periods of post-war Liberal revival and subsequent Liberal Democrat recovery - notably, that is, in the late 1950s/early 1960s, the early 1970s, and after 1990.

Of the SDP/Liberal Alliance decade of the 1980s, however, it can hardly be said that its most striking achievement - in securing the largest third-party vote share in Britain since the 1920s - could be attributed to new policy thinking. There were various reasons for that deficiency, which will be explored later in this study. With regard to one half of the Alliance, I should add that this book does not focus directly on the Social Democratic Party. That ground has already been substantially covered by a previous academic study. ${ }^{3}$ Nevertheless, I do consider the writings and pronouncements of leading SDP politicians and thinkers who later became prominent figures within the Liberal Democrats. I also examine at length the concept of a 
social market economy, controversial within parts of the Alliance, that was developed and promoted by David Owen during the 1980s.

Above all, I seek in this historical study to examine and elucidate the reasons for the revival since the late 1950s of Liberalism in Britain as a political philosophy. In addition, I hope to indicate why it has retained over the past half-century, in many eyes, its force, appeal and relevance as a creed, enduring into the radically changed political and economic climate of the early 21 st century. 


\section{Acknowledgements}

A number of people, concerned in their different ways with the political ideas, events and developments examined in this book, generously granted me interviews during its preparation. In several cases, too, they assisted me with my subsequent enquiries. I should therefore like to express my gratitude to the following: the Rt. Hon. Lord Ashdown of Norton-sub-Hampton, the Rt. Hon. Sir Alan Beith, MP, Duncan Brack, the Rt. Hon. Vince Cable, MP, the Rt. Hon. Sir Menzies Campbell, MP, the Rt. Hon. Nick Clegg, MP, the late Lord Dahrendorf of Clare Market, Dr Richard Grayson, Lord Greaves, Dr Evan Harris, the late Lord Holme of Cheltenham, David Howarth, Simon Hughes, MP, the Rt. Hon. Chris Huhne, MP, the Rt. Hon. Charles Kennedy, MP, Lord Kirkwood of Kirkhope, the Rt. Hon. David Laws, MP, Gordon Lishman, CBE, Lord Maclennan of Rogart, Professor David Marquand, Paul Marshall, Michael Meadowcroft, Richard Moore, the Rt. Hon. Lord Owen of the City of Plymouth, John Pardoe, Lord Phillips of Sudbury, Lord Rennard, Tony Richards, the Rt. Hon. Lord Rodgers of Quarry Bank, the late Lord Russell-Johnston, the Rt. Hon. Lord Steel of Aikwood, Lord Taverne, QC, Lord Wallace of Saltaire, and the Rt. Hon. Baroness Williams of Crosby.

Throughout the course of researching and writing this book, Duncan Brack and Michael Meadowcroft on numerous occasions shared with me their wide-ranging knowledge of contemporary British Liberal history and Liberal/Liberal Democrat politics, helping to clarify many points of detail. I am very grateful for their kind assistance. I should also like to thank Tony Richards, who made valuable comments on the first draft of Chapter 4, which in part covers the period when he and I were colleagues in London during the early 1970s.

My thanks are offered, too, to the staff of the New Bodleian Reading Room in the Bodleian Library, Oxford and the Rewley House Library, Oxford, where I spent many hours of study, as well as to the staff of the Nuffield College Library, Oxford and of the Archives Reading Room at the British Library of Political and Economic Science in London, where I was able to read many Liberal Party and SDP/Liberal Alliance publications and unpublished Liberal Party private papers.

For permission to reproduce material from Iain Dale (ed.) Liberal Party General Election Manifestos, 1900-1997 (London: Routledge/Politico's 2000), I should like to thank the Taylor Francis Group.

With regard to the practical completion of the book, I should like to acknowledge the helpful advice provided by Amber Stone-Galilee, Politics Editor at Palgrave Macmillan, and her editorial assistant Liz Blackmore, as 
well as the assistance of Rick Bouwman during the final stages. I should also like to thank Carolyn Gara, who typed the whole of the original text of this book with diligence, patience and good humour. I should like to record my gratitude, too, to Judith Arneil who typed and edited the final draft of the book, and to my friends Joanna Zang and Ani D, who assisted in that process. In a lighter vein, I owe my thanks, too, to the staff of 'Al-Andalus', 'The Rose and Crown', 'Saffron', ' $\mathrm{X}$ 'ian' and my other favourite haunts in Oxford, who alleviated the solitary routines of research and writing with sustenance, refreshment and good company.

Finally, I should like to convey my gratitude to my friend and colleague, Dr Alex Kazamias, for his continual encouragement whilst I was writing this book, and, more generally, for his friendship and kind generosity of spirit. 